\title{
Hemoglobin Binding Activity and Hemoglobin-Binding Protein of PREVOTELLA NIGRESCENS
}

\author{
M. Miyashita ${ }^{1}$, S. Oishi ${ }^{1}$, A. Kiso ${ }^{1}$, Y. Kikuchi², O. Ueda 2 , K. Hirai ${ }^{2}$, Y. Shibata ${ }^{3}$, S. Fujimura ${ }^{2}$ \\ ${ }^{1}$ Department of Oral Health Promotion, Graduate School of Oral Medicine, Matsumoto Dental University, Shiojiri-Nagano, Japan, \\ ${ }^{2}$ Department of Oral Microbiology, Matsumoto Dental University, Shiojiri-Nagano, Japan, \\ ${ }^{3}$ Division of Oral Health Promotion, Institute for Oral Science, Matsumoto Dental University, Shiojiri-Nagano, Japan
}

\begin{abstract}
Prevotella nigrescens, lacking siderophores was found to bind to the hemoproteins. The binding was observed also in the envelope which was prepared by sonication of the cell. The binding occurred in the $\mathrm{pH}$-dependent manner; the binding was observed below neutral $\mathrm{pHs}$ of the incubation mixtures but only slightly observed in the neutral and alkaline pHs. Furthermore, hemoglobin bound to the envelope was dissociated at high $\mathrm{pHs}$ buffers. Maximum amounts of hemoglobin bound to $1 \mathrm{mg}$ envelope was $51.2 \mu \mathrm{g}$. $\mathrm{Kd}$ for the reaction at $\mathrm{pH} 5.0$ was $2.1 \times 10^{-10} \mathrm{M}(210 \mathrm{pM})$. From the dot blot assay, hemoglobin could bind to a protein solubilized from the envelope by a detergent, referred to as hemoglobin-binding protein ( $\mathrm{HbBP}$ ), then it was purified by the sequential procedures of ion exchange chromatography, affinity chromatography and isoelectric focusing. Molecular weight and isoelectric point of the $\mathrm{HbBP}$ were $46 \mathrm{kDa}$ and 6.1 , respectively.
\end{abstract}

Key words: iron acquisition, periodontal pathogen, Prevotella nigrescens, hemoglobin, hemoproteins, hemoglobin-binding protein, purification, anaerobe

\section{INTRODUCTION}

Prevotella nigrescens is a gram-negative obligate anaerobic oral indigenous bacterial species. It forms characteristic jet-black colonies on the blood agar plates, as well as Porphyromonas gingivalis and Prevotella intermedia. These bacteria have been implicated in the pathogenesis of periodontitis, based on their ecological properties in the oral cavity and etiological characteristics including production of proteolytic enzymes [1-6] and endotoxin [7-10].

Even though pathogenic bacteria absolutely require iron, it is chelated by ferric binding proteins such as transferrin and lactoferrin or globulins. Therefore, concentration of free iron in the mammalian body fluids is extremely low, less than $10^{-18} \mathrm{M}$, which is far from the concentration to allow the bacterial growth [11-13]. Many pathogenic microorganisms elaborate siderophores which can chelate boundary iron with tremendously strong affinity to iron [14]. However, since the above stated periodontal pathogens are known to lack the siderophores [13, 14], they must possess other mechanism of iron acquisition. We have reported the binding activity to hemoproteins $[15,16]$ and isolation of hemoglobin binding protein (HbBP) from the envelope of $P$. gingivalis [17] which may function in the uptake process iron source from hemoglobin. In P. nigrescens, we also observed binding activity to hemoproteins. Then, we discuss the binding properties and purification of $\mathrm{HbBP}$.

\section{Materials And Methods}

\section{Bacterial Strain and Cultivation Methods}

P. nigrescens ATCC33563 was maintained on blood agar plates supplemented with hemin and menadione at $37^{\circ} \mathrm{C}$ in an anaerobic glove box filled with a mixture of gasses $\left(\mathrm{N}_{2}+\mathrm{H}_{2}+\mathrm{CO}_{2}, 85: 10: 5\right)$. The bacteria were inoculated into a medium consisting of $17 \mathrm{~g}$ of Trypticase peptone, $3 \mathrm{~g}$ of yeast extract, $2.5 \mathrm{~g}$ of glucose, $2.5 \mathrm{~g}$ of $\mathrm{K}_{2} \mathrm{HPO}_{4}, 5 \mathrm{~g}$ of $\mathrm{NaCl}, 5 \mathrm{mg}$ of hemin, and $0.5 \mathrm{mg}$ of menadione per liter and cultured anaerobically at $37^{\circ} \mathrm{C}$ for 3 days.

\section{Preparation of The Envelope and Solublization}

The cells were harvested by centrifugation at $12000 \times$ $\mathrm{g}$ and washed with saline and suspended in $50 \mathrm{mM}$ Tris-HCl buffer, $\mathrm{pH}$ 8.2. The cells were disrupted by ultrasonic treatment at $150 \mathrm{~W}$ for $20 \mathrm{~min}$. The sonicate was centrifuged at $7000 \times \mathrm{g}$ for $10 \mathrm{~min}$ and the precipitate containing unbroken cells and cell debris was discarded, on the other hand the supernatant represents the envelope was centrifuged at $120000 \times \mathrm{g}$ for $1 \mathrm{~h}$ to separate the envelope from cell extract. Then the envelope was washed with $50 \mathrm{mM}$ Tris- $\mathrm{HCl}$ buffer, $\mathrm{pH} 8.2$ by centrifugation at $120000 \times \mathrm{g}$ and resuspended in the same buffer. To a suspension of the envelope 3-[3-cholamidopropyl]-dimethylammoniol]propanesulfonate (CHAPS) was added to $0.5 \%$ and stirred for $5 \mathrm{~h}$. After incubation, the mixture was centrifuged at $120000 \times \mathrm{g}$ for $1 \mathrm{~h}$. The supernatant solution corresponding to the solubilized fraction of the envelope was kept at $-40{ }^{\circ} \mathrm{C}$ until use. The insoluble material was rinsed with $50 \mathrm{mM}$ Tris- $\mathrm{HCl}$ buffer, $\mathrm{pH}$ 8.2 by centrifugation at $120000 \times \mathrm{g}$ for $1 \mathrm{~h}$ and was referred to as outer membrane. 


\section{Dot Blot Assay of Hemoglobin Binding}

Horse radish peroxidase (Sigma Chemical Co., St. Louis, Mo) was oxidized with sodium periodate to form aldehyde groups within the enzyme molecules, and hemoglobin was coupled to this oxidized enzyme $[18,19]$. Binding of hemoglobin to HbBP of the envelope component was detected by using peroxidase-labeled hemoglobin and the method of Frangipaine et al. [20], including the application to nitrocellulose membranes, blocking with skim milk, and development with 4-chloro-1-naphthol-hydrogen peroxide.

\section{ExAminations of Binding ANd Dissociation of HEMOGLOBIN TO AND FROM THE ENVELOPE}

The amounts of hemoglobin bound to the envelope in the different $\mathrm{pH}$ buffers were determined by the essentially the same as our previous papers $[15,17]$. The envelope ( $4 \mathrm{mg}$ in wet weight) was mixed with $800 \mu \mathrm{l}$ of hemoglobin solution $(300 \mu \mathrm{g} / \mathrm{ml})$ in water, and $200 \mu \mathrm{l}$ of $0.5 \mathrm{M}$ buffer as described below; acetate buffer ( $\mathrm{pH} 4.5$ to 6.0 ), Tris-maleate buffer ( $\mathrm{pH} 6.5$ to 7.5), Tris- $\mathrm{HCl}$ buffer ( $\mathrm{pH} 8.0$ to 9.0 ), and carbonatebicarbonate buffer ( $\mathrm{pH} 9.5$ to 10.0). The mixtures were incubated at $37^{\circ} \mathrm{C}$ for $15 \mathrm{~min}$ and centrifuged at $120000 \times \mathrm{g}$. Unbound hemoglobin in the supernatant was measured by absorbance at $410 \mathrm{~nm}$ and the amount of bound hemoglobin was determined by subtraction. Binding of hemoglobin was tested also using the intact cell and the outer membrane.

Dissociation of hemoglobin from the complex of the envelope and hemoglobin formed in $50 \mathrm{mM}$ acetate buffer, $\mathrm{pH} 4.5$ was also examined in $\mathrm{pH}$ range from 4.5 to 10 . The degree of dissociation of hemoglobin was expressed as the amount of dissociated hemoglobin in each buffer versus completely released hemoglobin obtained by solubilization of the complex by CHAPS $[15,17]$.

\section{DETERMINATION OF BINDING OF HEMOPROTEINS TO} THE ENVELOPE

Photometrical method was employed to assay the amount of hemoproteins including hemoglobin, myoglobin, cytochrome $c$, and catalase bound to the envelope as described earlier [15]. Briefly, $5 \mathrm{mg}$ of the envelope was incubated with $270 \mu \mathrm{g}$ of human hemoglobin at $37{ }^{\circ} \mathrm{C}$ for $15 \mathrm{~min}$ and centrifuged. Unbound hemoglobin in the supernatant was measured by absorbance at $410 \mathrm{~nm}$ and the amounts of hemoglobin released from the formed envelope-hemoglobin complexes were compared using the same buffers described above.

\section{Purification OF HbBP}

All steps of purification were conducted at $4{ }^{\circ} \mathrm{C}$, if not otherwise stated.

Step 1: Ion exchange chromatography. The solubilized material of the envelope was applied to a column of Q-Sepharose $(1.5$ by $30 \mathrm{~cm})$, equilibrated with $50 \mathrm{mM}$ Tris- $\mathrm{HCl}$ buffer $(\mathrm{pH} 8.2)$ and the column was washed with the same buffer thoroughly until the eluates of the $A_{280}$ was reached less than 0.05. Then the column was eluted with a linear concentration gradient of $\mathrm{NaCl}$ from 0 to $1.0 \mathrm{M}$, which was generated by mixing $200 \mathrm{ml}$ of $50 \mathrm{mM}$ Tris- $\mathrm{HCl}$ buffer ( $\mathrm{pH} 8.2$ ) containing 1.0 $\mathrm{M} \mathrm{NaCl}$ into an equal volume of $50 \mathrm{mM}$ Tris- $\mathrm{HCl}$ buffer ( $\mathrm{pH}$ 8.2). The flow rate was $20 \mathrm{ml} / \mathrm{h}$, and $5 \mathrm{ml}$ fractions were collected. The active fractions confirmed by dot blot assay were combined and dialyzed against $50 \mathrm{mM}$ acetate buffer ( $\mathrm{pH} 4.5)$ for $20 \mathrm{~h}$. The insoluble material generated in the dialysis bag was removed by centrifugation at $12000 \times \mathrm{g}$ for $20 \mathrm{~min}$.

Step 2: Affinity chromatography. The dialyzed material was applied to a column $(1$ by $13 \mathrm{~cm}$ ) of hemoglobinconjugated agarose (Sigma) equilibrated with $50 \mathrm{mM}$ acetate buffer ( $\mathrm{pH}$ 4.5). The column was washed with the same buffer until the $A_{280}$ of eluates was less than

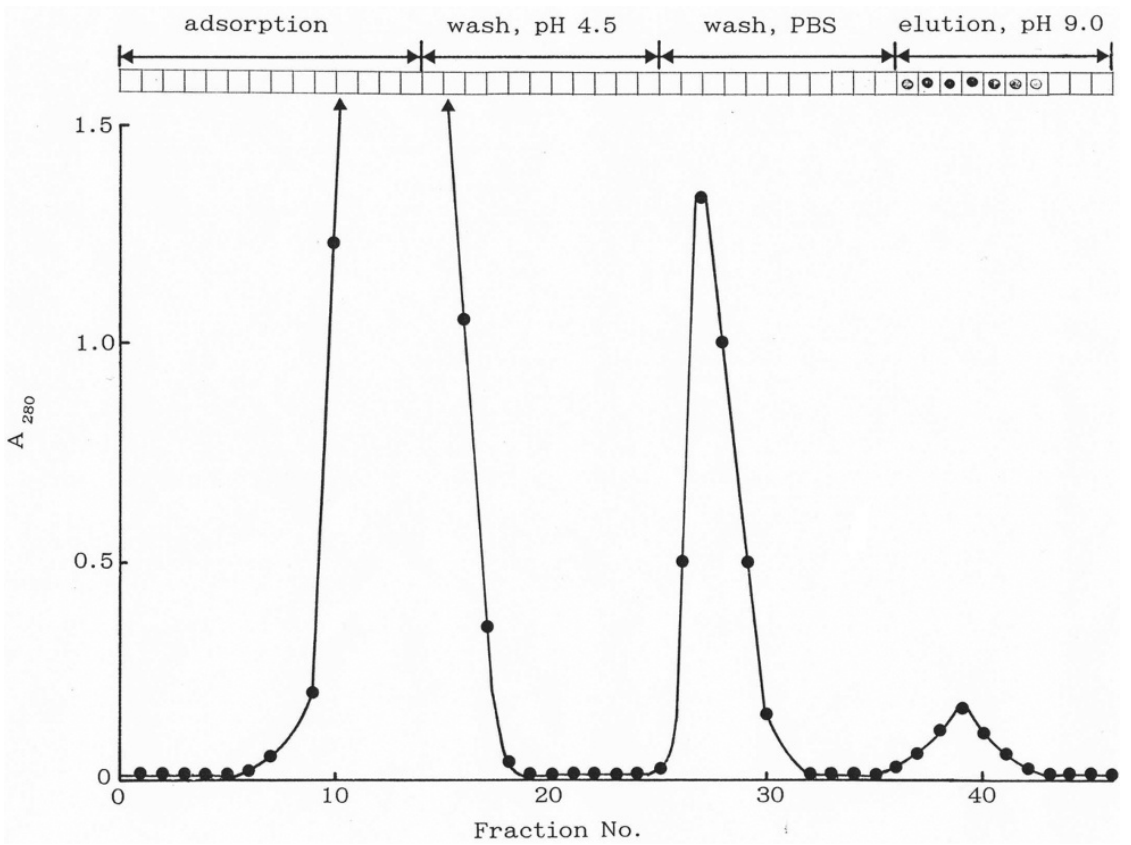

Fig. 1. Affinity chromatography of HbBP. The hemoglobin binding activity determined by dot blot assay is presented at the top of figure. 
0.05 and then the column was washed with $50 \mathrm{mM}$ phosphate buffer (pH 7.0) containing $150 \mathrm{mM} \mathrm{NaCl}$ (PBS). Finally the column was eluted with $50 \mathrm{mM}$ Tris$\mathrm{HCl}$ buffer, $\mathrm{pH}$ 9.0. Hemoglobin binding activity was found only in the fractions eluted with the $\mathrm{pH} 9.0$ buffer (Fig. 1). The active fractions were combined and dialyzed against $1 \%$ glycine solution.

Step 3: Isoelectric foucusing. The dialyzed material was subjected to isoelectric focusing electrophoresis. Electrophoresis was carried out using $1 \%(\mathrm{v} / \mathrm{v})$ ampholine (pH 3-10) under constant voltage (300 V) with cooling the column by tap water. After the electrophoresis, column contents were collected into $2 \mathrm{ml}$ fractions. HbBP activities of each fraction were determined by dot blot assay and $\mathrm{pH}$ values were measured. The active fractions were dialyzed against $50 \mathrm{mM}$ acetate buffer $\mathrm{pH}$ 4.5 and stored at $-30^{\circ} \mathrm{C}$ as the purified $\mathrm{HbBP}$.

\section{SDS-POLyaCrylamide GEL EleCtrophorrsis (SDS-PAGE)}

SDS-PAGE was carried out using $12.5 \%$ polyacrylamide. Molecular mass markers were phosphorylase $\mathrm{b}$ (94 kDa), bovine serum albumin $(67 \mathrm{kDa})$, ovalbumin (43 kDa), carbonic anhydrase $(30 \mathrm{kDa})$, trypsin inhibitor $(20 \mathrm{kDa})$, and $\alpha$-lactalbumin $(14 \mathrm{kDa})$.

\section{RESULTS}

\section{BINDING OF HEMOGLOBIN AND OTHER} Hemoproteins to THE Cellular Components

Effects of different $\mathrm{pH}$ values on the binding of hemoglobin to the envelope was noteworthy. Hemoglobin in the $\mathrm{pH} 4.5$ buffer solution was found to bind

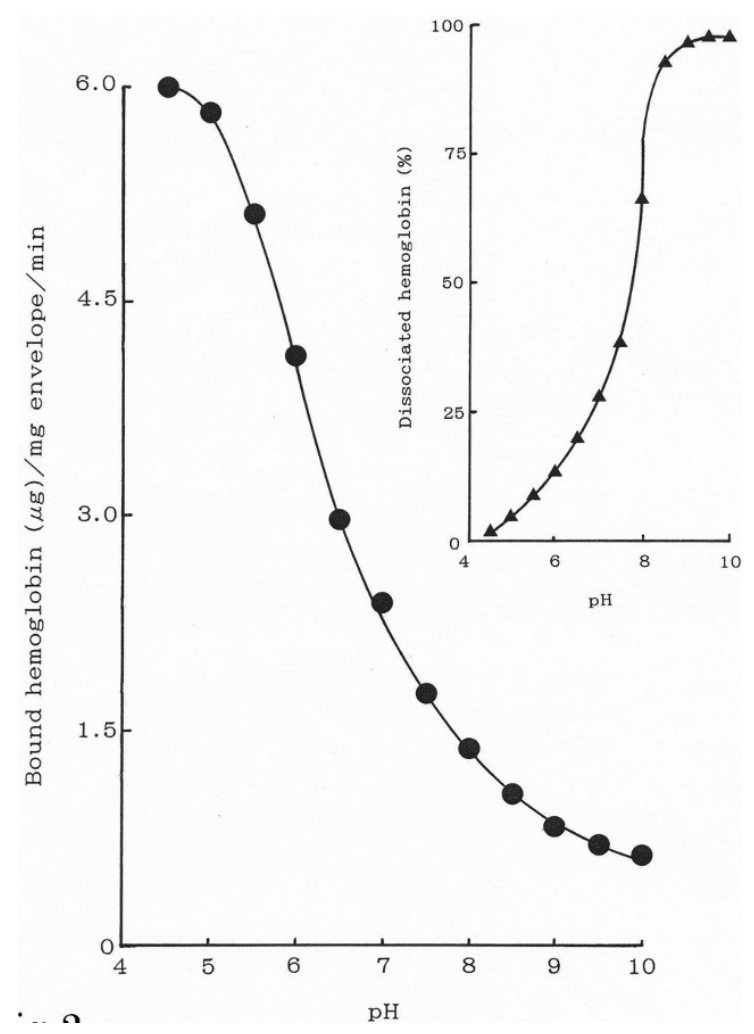

Fig. 2. Reversible binding of hemoglobin to the envelope.

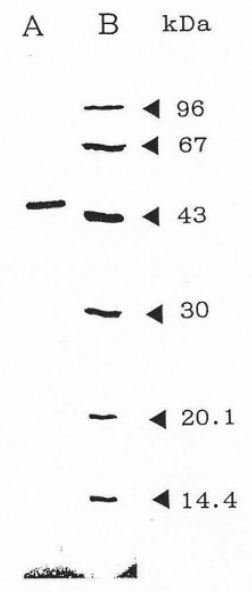

Fig. 3. SDS-PAGE of purified HbBP. A: Purified HbBP, B: Marker proteins.

completely to the envelope. The binding rates reduced as a function of lowering of the $\mathrm{pH}$ values to 8.0. Only slight binding occurred at pHs 8.5 to 10 (Fig. 3). When the established hemoglobin-envelope complex formed in the $\mathrm{pH} 4.5$ solution was immersed in the $\mathrm{pH} 9.0$ solution, hemoglobin released entirely from the envelope. However, dissociation was not vigorous in neutral and acidic solutions. These findings demonstrate that effects of $\mathrm{pH}$ on binding and dissociation among hemoglobin and the envelope is rightly reciprocal; HbBP in the envelope prefers acidic conditions to alkaline conditions in the hemoglobin binding reaction. Additionally, hemoglobin bound to the envelope easily dissociate in the alkaline solutions (Fig. 2).

Binding of five kinds of hemoproteins including hemoglobin, myoglobin, cytochrome c, catalase, and holo-transferrin to the envelope was tested in $50 \mathrm{mM}$ acetate buffer, $\mathrm{pH}$ 4.5. As shown in Table 1, high amounts of hemoglobin and myoglobin were found to bind to the envelope. Considering myoglobin is a quarter moiety of hemoglobin molecule, the close degree of the binding seems to be reasonable. However, binding of cytochrome $c$ and catalase was obviously weaker than that of hemoglobin and myoglobin. No significant binding was confirmed in holo-transferrin.

Comparative evaluation of binding of hemoglobin to the intact cell, envelope, and outer membrane was tested. The ratio of the activity of these components was $100: 70: 5: 1.9$.

Table 1. Binding of the Envelope to Hemoproteins.

Hemoproteins Initial amounts $(\mu \mathrm{g}) \quad$ Bound amounts $(\mu \mathrm{g})$

\begin{tabular}{llr}
\hline Hemoglobin & 270 & 266 \\
Myoglobin & 270 & 240 \\
Cytochrome $c$ & 270 & 121 \\
Catalase & 270 & 99 \\
holo-Transferrin & 270 & 14 \\
\hline
\end{tabular}

(Reactions were conducted in $50 \mathrm{mM}$ acetate buffer, $\mathrm{pH}$ 4.5, using $5 \mathrm{mg}$ envelope) 
Dissociastion Constant of Hemoglobin to the ENVELOPE

From the plots of increasing amounts of hemoglobin and the amounts of hemoglobin bound to the envelope (Scatchard plot), hemoglobin binding to the envelope determined an apparent dissociation constant $(\mathrm{Kd})$ of $210 \mathrm{pM}$ (data are not shown).

\section{Purity of HbBP, Molecular Weight, AND IsOELECTRIC PoINT}

Isoelectric point was 6.1 judged from the isoelectric foucusing electrophoresis. The finally purified HbBP showed a single stained band in the SDS-PAGE, indicating this sample was purified to homogeneity. The molecular mass was estimated as $46 \mathrm{kDa}$ as illustrate in (Fig. 3).

\section{Binding of HbBP to Hemoproteins}

Dot-blot determination demonstrated purified HbBP bound actively to hemoglobin and myoglobin, moderately to cytochrome $c$, and weakly to catalase. However, binding to holo-transferrin was found to be negative.

\section{Thermostability AND RESISTANCE TO VARIOUS REAGENTS}

Heating of the envelope at $65^{\circ} \mathrm{C}$ for $20 \mathrm{~min}$ resulted in the loss of hemoglobin-binding activity of $12 \%$. Similarly, the titer of the purified HbBP demonstrated one eighth activity after the same heating.

When the envelope and the purified HbBP were treated by trypsin $(1 \mathrm{mg} / \mathrm{ml})$ and chymotrypsin (1 $\mathrm{mg} / \mathrm{ml}$ ) at $37{ }^{\circ} \mathrm{C}$ for $30 \mathrm{~min}$, separately, no significant decrease of hemoglobin binding activity was seen.

Neither inhibition nor activation of the hemoglobin binding activity of the envelope was observed by the incubation for $30 \mathrm{~min}$ by the following reagents; $\mathrm{Ca}^{2+}(1 \mathrm{mM}), \mathrm{Mg}^{2+}(1 \mathrm{mM}), \mathrm{Mn}^{2+}(1 \mathrm{mM}), \mathrm{Fe}^{2+}(1 \mathrm{mM})$, EDTA (20mM), EGTA (20 mM), 1,10-phenanthrolin $(50 \mathrm{mM})$, mercaptoethanol $(5 \mathrm{mM})$, Leupeptin $(2 \mathrm{mM})$, Antipain (10 mM), L-trans-Epoxy-succinylleucyl-amido-(4-guanidino)butane (E64) (2 mM), 4-(2-Aminoethyl)-benzenesulfonylfluoride(Pefabloc SC) (2 mM).

\section{Discussion}

Usually, hemin is added to the ordinary medium as an iron source in the cultivation of the black pigmented periodontal pathogens. Since, hemin can be replaced by hemoglobin, it also is a possible source of iron in vivo for the species lacking siderophores as well as hemin. But it may be practically impossible to expect that the body fluids contain sufficient amounts of hemin to support the growth of these bacteria. On the contrary, in the diseased sites of periodontitis, red blood cells may be adequately supplied, which contributes to provide hemoglobin.

We confirmed binding activity of the envelope to hemoglobin. Its binding activity was remarkably affected by the differences in $\mathrm{pH}$ values of the incuba- tion mixtures; binding was observed in the lower $\mathrm{pHs}$ buffer ( $\mathrm{pH} 4.5$ to 6.0 ) but only poor binding was found in neutral $\mathrm{pH}$ buffer, and no significant binding in the alkaline pHs buffer. Moreover, dissociation of hemoglobin from the established complex of the envelope and hemoglobin in alkaline condition was observed. These properties are quite similar to the findings in the case of $P$. gingivalis [17].

The properties of HbBP of $P$. nigrescens are generally similar to those of $P$. gingivalis, however, a substantial difference is noticed in the molecular masses of HbBP; that of P. gingivalis was $19 \mathrm{kDa}$ [17], but it was $46 \mathrm{kDa}$ in $P$. nigrescens. The chemical difference was seen in $\mathrm{pIs}$ between $P$. nigrescens and $P$. gingivalis. We estimated $\mathrm{pI}$ as 6.1 in this report, but in $P$. gingivalis it was 4.3 [17]. These observations indicate that the molecules of HbBPs of the two species are different from each other, but possess the similar properties in the mode of hemoglobin binding.

The fact that intact cell was found to actively bind to hemoglobin may be functionally useful to catch hemoglobin from the bacterial environment. However, the binding activity of the outer membrane was quite low (Fig. 1). Guan et al. reported that hemoglobin binding activity was confirmed in the outer membrane in $P$. intermedia, and a protein responsible for the binding to hemoglobin was isolated from the outer membrane, its molecular mass was $60 \mathrm{kDa}$ [21], however $\mathrm{HbBP}$ of $P$. nigrescens was $46 \mathrm{kDa}$. These discrepancies may be due to the difference of bacterial species, even if both species are rather close each other.

According a report of $\mathrm{HbBP}$ of P. nigrescens [22], it was also active in low $\mathrm{pH}$ buffers than at higher $\mathrm{pH}$. Its activity was resistant to heating at $60^{\circ} \mathrm{C}$ for 10 min, but obvious decrease was observed heating at $80^{\circ} \mathrm{C}$. Treatment of the intact cells by trypsin resulted in about $35 \%$ loss of the binding activity. Furthermore, in the extracted materials of the cells by $n$ octyl- $\beta$-D-thioglucoside, three proteins possessing molecular masses of $41 \mathrm{kDa}, 56 \mathrm{kDa}$, and $59 \mathrm{kDa}$ reacted to hemoglobin were detected. The differences of the properties from our results, particularly in the molecular masses, may be due to the different protein source, detergent extracts of the intact cells and the envelope.

\section{REFERENCES}

1. Bedi G.S, Williams T (1994) Purification and characterization of a collagen-degrading protease from Porphyromonas gingivalis. J Biol Chem 269:599-606

2. Fujimura S, Shibata Y, Nakamura T (1992) Comparative studies of three proteases of Porphyromonas gingivalis. Oral Microbiol Immunol 7:212-217

3. Hinode D, Hayashi H, Nakamura R (1991) Purification and characterization of three types of proteases from culture supernatants of Porphyromonas gingivalis. Infect Immun 59:3060-3068

4. Kadowaki T, Yoneda M, Okamoto K, Maeda K, Yamamoto K (1994) Purification and characterization of a novel arginine- specific cysteine protease (argingipain) involved in the pathogenesis of periodontal disease from the culture supernatant of Porphyromonas gingivalis. J Biol Chem 269:21371-21378

5. Lewis JP, Dawson JA, Hannis JC, Muddiman D, Macrina FL (1999) Hemoglobinase activity of the lysine gingipain 
protease (Kgp) of Porphyromonas gingivalis W83. J Bacteriol 181:4905-4913

6. Pike R, McGraw W, Potempa J, Travis J (1994) Lysineand arginine-specific proteases from Porphyromonas gingivalis. Isolation, characterization, and evidence for the existence of complexes with hemagglutinins. J Biol Chem 269:406-411

7. Bramanti TE, Wong GG, Weintraub ST, Holt SC (1989) Chemical characterization and biologic properties of lipopolysaccharide from Bacteroides gingivalis stain W50, W83 and ATCC 33277. Oral Microbiol Immunol 4:183192

8. Hamada S, Okahashi N, Fujiwara T, Nishihara T, Koga T (1988) Selective induction of prostagrandin E production in $\mathrm{C} 3 \mathrm{H} / \mathrm{HeJ}$ mouse macrophages by lipopolysaccharides from Bacteroides gingivalis. Oral Microbiol Immunol 3:196-198

9. Shenker BJ. Slots J (1989) Immunomodulatory effects of Bacteroides products in in vitro human lymphocyte functions. Oral Microbiol Immunol 4:24-29

10. Yamazaki K, Ikarashi F, Aoyagi T, Takahashi K, Nakajima T, Hara K Seymoure, GJ. (1992) Direct and indirect effects of Porphyromonas gingivalis lipopolysaccharide on interleukin-6 production by human gingival fibroblasts. Oral Microbiol Immunol 7:218-224

11. Eskew JD, Vanacore RM, Sung L, Morales PJ, Smith A (1999) Cellular protection mechanisms against extracellular heme: heme-hemopexin, but not free heme, activates the N-terminal c-Jun kinase. J Biol Chem 274:638-648

12. Fouz B, Mazoy R, Vazquez F, Lemos L, Amaro, C (1997) Isolation of hemin and hemoglobin binding outer membrane protein of Vibrio vulfnificus biotype 2 (serogroup E). FEMS Microbiol Lett 156:187-191

13. Griffiths WTH, Kelly AL, Smith SJ, Cox TM (2000) Localization of iron transport and regulatory proteins in human cells. Q J Med 93:575-585

14. Bullen JJ, Rogers HJ, Griffiths E (1978) Role of iron in bacterial infection. Curr Top Microbiol Immunol 80:1-35

15. Fujimura S, Shibata Y, Hirai K, Nakamura T (1995) Some binding properties of the envelope of Porphyromonas gingivalis to hemoglobin. FEMS Immunol Med Microbiol 10:109-114
16. Fujimura S, Nakamura T (2000) Binding and utilization of myoglobin by Porphyromonas gingivalis. FEMS Microbiol Lett 184:247-251

17. Fujimura S, Shibata Y, Hirai K, Nakamura T (1996) Binding of hemoglobin to the envelope of Porphyromonas gingivalis and isolation of the hemoglobin-binding protein. Infect Immun 64:2339-2342

18. Kishore AR, Erdie J, Kalfas S, Forsgren A, Naidu AS (1992) Detection of bacterial interaction with lactoferrin by an enzyme-linked ligand binding assay (ELBA). J Med Microbiol 37:341-345

19. Nakane P, Kawaoi A (1974) Peroxidase-labeled antibody. A new method of conjugation. J Hidtochem Cytochem 22:22-27

20. Frangipane MED, Morton D, Wooten JA, Pozsgay JM, Stull TL (1994) Binding of human hemoglobin by Haemophilus influenzae. FEMS Microbiol Lett 118:243248

21. Guan S-M, Nagata H, Kuboniwa M, Minamino N, Shizukuishi S (2004) Purification and characterization of hemoglobin-binding outer membrane protein of Prevotella intermedia. FEMS Microbiol Lett 235:333-339

22. Guan S, Nagata H, Kuboniwa M, Ikawa Y, Maeda K, Shizukuishi S (2006) Characterization of binding and utilization of hemoglobin by Prevotella nigrescens. Oral Microbiol Immunol 17:157-162

Received: October 29, 2009 / Accepted: January 25, 2010

Address for correspondence:

Setsuo Fujimura, D.Sc.

Department of Oral Microbiology

Matsumoto Dental University,

1780 Hirooka-Gobara,

Shiojiri-Shi, Nagano-Ken

399-0781 Japan

Phone/Fax: +81(263)51-2084

E-mail: fujimura@po.mdu.ac.jp 